\title{
PROMICANJE EKOLOŠKE OSVIJEŠTENOSTI PROJEKTOM „ZELENA KNJIŽNICA“ DRUŠTVA BIBLIOTEKARA ISTRE
}

\author{
PROMOTING ENVIRONMENTAL AWARENESS \\ WITH THE PROJECT "GREEN LIBRARY” OF THE \\ ASSOCIATION OF LIBRARIANS OF ISTRIA
}

Ivan Kraljević

Sveučilišna knjižnica

Sveučilište Jurja Dobrile u Puli

kivan@unipu.hr

Kristina Afrić Rakitovac

Sveučilišna knjižnica

Sveučilište Jurja Dobrile u Puli

kafric@unipu.hr

\author{
UDK / UDC: [027.3:502/504]: \\ 061.2:02(497.571)DBI \\ Stručni rad / Professional paper \\ Primljeno / Received: 15. 10. 2020. \\ Prihvaćeno / Accepted: 20. 8. 2021.
}

\section{Sažetak}

Cilj. U članku se govori o nastanku i aktivnostima projekta "Zelena knjižnica" u Istarskoj županiji. Cilj je rada omogućiti uvid u razloge nastanka i kronologiju djelovanja u sklopu projekta te ukazati na doprinos zelene knjižnice ekološkoj osviještenosti i ekološkoj pismenosti različitih dionika u lokalnoj zajednici.

Metodologija. Analizom projekta "Zelena knjižnica" autori iznose prikaz djelovanja kroz projekt te utjecaja projekta na zajednicu.

Rezultati. Rezultat rada jest prikaz djelovanja u sklopu projekta "Zelena knjižnica" od začetka ideje o projektu 2010. godine do kraja 2019. godine.

Društveni značaj. Predstavljanje dobre prakse prvog projekta "Zelena knjižnica" koji je posložio kao uzor sličnim projektima.

Vjesnik bibliotekara Hrvatske 64, 2(2021), 399-423

ISSN 0507-1925 
Originalnost. Prvi prikaz svih aktivnosti u sklopu projekta "Zelena knjižnica" od samog početka 2011. godine do kraja 2019. godine.

Ključne riječi: edukacija, lokalna zajednica, održivo društvo, zaštita okoliša, zelena knjižnica.

\section{Abstract}

Goal. The paper discusses the origin and activities of the "Green Library" project in the County of Istria. The aim of the paper is to provide insight into the reasons for launching the project, chronology of the activities within the project, and point out the contribution of the green library to the environmental awareness and environmental literacy of various stakeholders and interested parties in the local community.

Methodology. Through an analysis of the "Green Library" project, the authors present the project activities and the impact of the project on the community.

Results. The outcome of the paper is a presentation of all activities within the "Green Library" project from the initial project idea in 2010 to the end of 2019.

Social significance. Presentation of the good practice of the first "Green Library" project, which later served as a model for similar projects.

Originality. The first presentation of all activities within the "Green Library" project from the very beginning in 2011 to the end of 2019.

Keywords: education, environmental protection, green library, local community, sustainable society

\section{Uvod}

Suvremeno, rizično društvo suočava se s brojnim ekonomskim, društvenim, kulturološkim, ekološkim, političkim i drugim izazovima koji su nerijetko uzrokovani neodgovornim i neetičkim korištenjem raspoloživih ljudskih, prirodnih i materijalni resursa. Navedeno ukazuje na nužnost podizanja ekološke osviještenosti i ekološke pismenosti svih dionika u društvu. U radu se razmatra uloga knjižnica u procesu osvješćivanja društva. Rad se usredotočuje na zelene knjižnice cilj kojih jest edukacija javnosti i širenje svijesti o održivom društvu i nužnosti zaštite okoliša.

Začetak ideje o projektu "Zelena knjižnica" dogodio se 29. studenog 2010. godine u Puli. ${ }^{1}$ U organizaciji Društva bibliotekara Istre i Sveučilišta Jurja Dobrile u Puli održana je tog dana u 13 sati projekcija filma „Dom“ Yanna Arthusa

\footnotetext{
1 „Dom“Yanna Arthusa-BertrandanaSveučilištuJurjaDobrileuPuli. SveučilišteJurjaDobrileuPuli.[citirano: 2020-05-12]. Dostupno na: http://e-nastava.unipu.hr/index.php?id=77\&L=1\%25\%2527\&tx ttnews\%5Btt_news\%5D=8286\&cHash=b9efd16a2446e4dd445875a29bc684b1.
} 
Bertranda na Odjelu za ekonomiju i turizam „Dr. Mijo Mirković“. ${ }^{2}$ Sve se to odvilo povodom Međunarodne godine biološke raznolikosti na inicijativu tadašnjeg predsjednika Društva bibliotekara Istre Ivana Kraljevića te uz podršku tadašnje voditeljice Sveučilišne knjižnice Tijane Barbić-Domazet. Film je pogledalo stotinjak studenata, a više lokalnih medija pokazalo je veliku zainteresiranost za događaj. To je bio inicijalni trenutak za učiniti nešto više što bi kontinuirano povezivalo ekologiju i knjižničarstvo i tako je osmišljen projekt kojim bi se kroz knjižnice i knjižničarska društva promicala ideja održivog društva i zaštite okoliša. Sličan projekt u Hrvatskoj u tom trenutku nije postojao, a naziv Zelena knjižnica nekako se logično nametnuo. Autor je projekta Ivan Kraljević iz Sveučilišne knjižnice u Puli koji projekt u sklopu Društva bibliotekara Istre službeno vodi od 2011. godine. Te 2011. godine Društvo još nije stiglo prijaviti projekt na natječaje, ali je ipak s minimalnim vlastitim sredstvima održalo 17 aktivnosti. ${ }^{3}$

Cilj je rada omogućiti uvid u razloge nastanka i kronologiju djelovanja u sklopu projekta „Zelena knjižnica“ te ukazati na njegov doprinos ekološkoj osviještenosti i ekološkoj pismenosti različitih dionika u lokalnoj zajednici. Rad je izrađen na temelju sekundarnih izvora literature te analize godišnjih izvještaja projekta "Zelena knjižnica" od 2010. do 2019. godine.

Može se pretpostaviti da je projekt „Zelena knjižnica“ pridonio osvješćivanju brojnih studenata i šire javnosti u gradu Puli te širenju sličnih inicijativa u knjižnicama diljem zemlje.

\section{Uloga zelenih knjižnica u promicanju ekološke osviještenosti i ja- čanju ekološke pismenosti}

Čovjek je od svog nastanka utjecao na prirodni okoliš. No antropogeni utjecaj na okoliš intenziviran je tijekom industrijskih revolucija, od druge polovine 18. stoljeća do danas. Antropogeni učinci na globalni ekosustav sve su intenzivniji tijekom proteklih pedeset godina. U tom razdoblju dogodio se vrlo dinamičan rast međunarodne trgovine, međunarodnog prometa i potrošnje, eksponencijalni rast stanovništva, intenzivirana je urbanizacija i deruralizacija i dr. Sve navedeno utjecalo je na sve bržu potrošnju prirodnih resursa, povećano onečišćenje okoliša, klimatske promjene, postupnu razgradnju stratosferskog sloja ozona, smanjenje snježnog i ledenog pokrivača, deforestaciju, degradaciju i osiromašenje tla, intenzivan gubitak biološke i kulturne raznolikosti te na produbljivanje jaza između razvijenih nerazvijenih zemalja.

\footnotetext{
2 Osnivanjem Sveučilišta Jurja Dobrile u Puli u prosincu 2006. godine, tadašnji Fakultet ekonomije i turizma ulazi u njegov sastav te postaje Odjel za ekonomiju i turizam „Dr. Mijo Mirković“, a status fakulteta ponovno dobiva 2013. godine.

3 Usp. Kraljević, I. Djelovanje Radne grupe za zelene knjižnice 2014.-2018. // Vjesnik bibliotekara. 62, 1(2019), 327-340.
} 
Intenzivan „pritisak“ na okoliš, osobito od 1970-ih godina, uzrokovao je niz ekoloških problema koji rezultiraju ekološkom krizom, a koja je u svoj biti „,kriza odnosa čovjeka prema okolišu“. Šimleša još 2010. godine uočava da se istovremeno događa porast ekološkog otiska i pad biokapaciteta. ${ }^{4}$ World Wide Fund 2020. godine jasno ukazuje na činjenicu da je čovjekov utjecaj na prirodni okoliš sve veći. Prema navedenom izvoru, između 1970. i 2016. godine dogodio se pad promatrane populacije životinja (sisavaca, ptica, vodozemaca, reptila i riba) od $68 \%$. Na godišnjoj razini, čovječanstvo troši 1,56 biokapaciteta planeta Zemlje, tj. 56 \% više od godišnjeg biokapaciteta. Slikovito rečeno, zadovoljenje potreba čovječanstva iziskuje jedan i pol planet godišnje. ${ }^{5}$

Ekološka se kriza događa istovremeno s krizom društva i društvenih odnosa koji rezultiraju na globalnoj, nacionalnoj i lokalnoj razini, sve većim jazom između sve bogatije manjine i sve siromašnije i obespravljenije većine, sve većim razlikama u životnim uvjetima i kvaliteti života.

Prema Oxfamu, u 2019. godini vrijednost bogatstva 2,153 milijardera bila je veća od onog koje posjeduje 4,6 milijardi ljudi. Najbogatijih $1 \%$ ljudi na svijetu ima više nego dvostruko veće bogatstvo od 6,9 milijardi ljudi. ${ }^{6}$

Preduvjet nužnih društvenih promjena i promjena odnosa prema okolišu jest osvješćivanje problema, razumijevanje uzročno-posljedičnih odnosa te spremnost na osviješteno ponašanje svih dionika u društvu, tj. opće populacije, gospodarstvenika, javnih institucija, nositelja političke vlasti, civilnog društva i dr.

Ekološka svijest je, prema Cifriću, u najširem smislu samosvijest o djelovanju u prirodi i oblikovanju okoliša radi vlastite prilagodbe sa što manjim negativnim posljedicama za život. Proces oblikovanja ekološke svijesti ima nekoliko dimenzija: „kognitivna“ (znanje) dimenzija - ekološko razumijevanje: znanje o objektivnim činjenicama o prirodi, ekološkim procesima i njihovoj povezanosti, „afektivna“ (osjećaji) - osobna pogođenost; osjećaji, strahovi nadanja i „konativna“ (akcijska) dimenzija - ponašanje i izražena spremnost na akciju. ${ }^{7}$ Ekološka pismenost, kako je definiraju Disinger i Roth, određuje se kao sposobnost uvida

\footnotetext{
4 Šimleša, D. Ekološki otisak: Kako je razvoj zgazio održivost. Zagreb: Tim Press, Institut društvenih znanosti Ivo Pilar, 2010. Str. 34.

5 World Wide Fund. Living planet report 2020: Bending the curve of biodiversity loss. [citirano: 2020-07-10]. Dostupno na: https://f.hubspotusercontent20.net/hubfs/4783129/LPR/PDFs/ ENGLISH-FULL.pdf.

6 Coffey, C.; P. Espinoza Revollo; R. Harvey; M. Lawson; A. Parvez Butt; K. Piaget; D. Sarosi i suradnici. Time to care: Unpaid and underpaid care work and the global inequality crisis. Oxford: Oxfam International, 2020. Str.10 [citirano: 2020-06-10]. Dostupno na: https://oxfamilibrary.openrepository.com/bitstream/handle/10546/620928/bp-time-to-careinequality-200120-en.pdf.

7 Bolts, H. Umwelterziehung: Grundlagen, Kritik und Modelle für die Praxis. Darmstadt: Wissenschaftliche Buchgesellschaft, 1995. Citirano prema: Cifrić, I. Ekološka edukacija: Utjecaj na oblikovanje novog identiteta? // Filozofska istraživanja 25, 2(2005), str. 338.
} 
i procjene relativnog stanja okoliša i poduzimanje odgovarajućih mjera i akcija radi njezina očuvanja, obnove i poboljšanja. ${ }^{8}$ Prema Cifriću, ekološka pismenost ne odnosi se samo na pojedinca već i na društvo. Odnosno, tranzicija sa sadašnjeg neodrživog modela razmišljanja i ponašanja ka održivijom kreće od osobne razine prema podizanju ekološke pismenosti šireg društva. Prema istom autoru, za suvremeno društvo bilo bi poželjno imati razinu ekološke pismenosti pojedinaca koja bi predstavljala rutinizirano svakodnevno ponašanje koje prelazi u naviku, odnosno „stanje praktične svijesti“.”

Zelene knjižnice pridonose promicanju ekološke svijenosti i ekološke pismenosti. Dragaš je prikazala ulogu knjižnice u jačanju svijesti o održivom razvoju društva i nužnosti zaštite okoliša. Autorica navodi kako je Međunarodni savez knjižničarskih društava i ustanova (engl. The International Federation of Library Associations and Institutions - IFLA) u svojoj „Izjavi o knjižnicama i razvitku“ (2013) naglasio da knjižnice pružaju pristup informacijskim sadržajima i uslugama koje podupiru održivi razvoj te mogu biti provoditelji programa ekološkog osvješćivanja zajednice. Prema istom izvoru, uloga knjižnica u promicanju održiva razvoja istaknuta je i u IFLA-inu i UNESCO-ovu Manifestu za narodne knjižnice. ${ }^{10}$ Nadalje, IFLA je prepoznala ulogu knjižnica u promicanju i implementaciji svih Ciljeva održiva razvoja 2030 (Sustainable Development Goals SDGs 2030) promicanjem opće pismenosti (uključujući medijsku, informacijsku i digitalnu pismenost), omogućavanjem digitalne inkluzije (olakšavanjem pristupa informacijsko-komunikacijskoj tehnologiji), čuvanjem i osiguravanjem pristupa kulturnoj baštini i dr."“11

IFLA je pokrenula i projekt pod nazivom „Library Map of the World“ kojim poziva knjižnice na dijeljenje poticajnih primjera dobre prakse koji pridonose realizaciji navedenih ciljeva. Do rujna 2020. godine prikazan je 41 projekt iz 25 zemalja diljem svijeta. Najveći dio projekata (27/41) odnosi se na Cilj 4: Osigurati uključivo i kvalitetno obrazovanje te promovirati mogućnosti cjeloživotnoga učenja za sve. Iz Hrvatske se prikazuje samo jedan projekt, tj. projekt "Zelene knjižnice" Filozofskog fakulteta Sveučilišta u Zagrebu. ${ }^{12}$

\footnotetext{
8 Disinger, J.F.; C.E. Roth. Environmental literacy. // ERIC Clearinghouse for Science, Mathematics, and Environmental Education, Columbus Ohio, 1992. Str. 3. [citirano: 2020-06-10]. Dostupno na: https://files.eric.ed.gov/fulltext/ED351201.pdf.

9 Cifrić, I. Ekološka pismenost između kulturne tradicije i ekološke svakodnevnice. // Socijalna ekologija 5, 3(1996), str. 418.

10 Dragaš, B. Zelene knjižnice za zelenu pismenost: Hrvatsko iskustvo. // Vjesnik bibliotekara Hrvatske 60, 4(2017), str. 221-241.

${ }^{11}$ IFLA. Upute: Knjižnice, razvoj i UN-ova AGENDA 2030, kolovoz 2017. Revidirano izd. // Vjesnik bibliotekara Hrvatske 61, 2(2018), str. 519-543. Vidjeti i: IFLA (2016): Pristup i mogućnost svima: Kako knjižnice doprinose ostvarivanju Agende Ujedinjenih naroda za održiv razvoj 2030. [citirano: 2020-09-01]. Dostupno na: www.hrdrustvo.hr.

12 Library Map of the World. [citirano: 2020-06-12]. Dostupno na: https://librarymap.ifla.org.
} 


\section{Projekt „Zelena knjižnica“6 - kratki pregled}

„Zelena knjižnica“ je projekt Društva bibliotekara Istre nastao 2011. godine. Prvi je to takav projekt u Hrvatskoj, najdugovječniji i ujedno projekt s najviše provedenih aktivnosti u zadnjih devet godina. Cilj je projekta preko Društva bibliotekara Istre $i$ istarskih knjižnica educirati javnost i širiti svijest o održivom društvu i nužnosti zaštite okoliša i to kroz: portal Zelena knjižnica, projekcije dokumentarnih filmova, stručna predavanja, tribine i promocije knjiga. ${ }^{13}$

Korisnici su projekta u prvom redu učenici i studenti, ali i šira javnost. Od 2011. godine aktivnostima projekta obuhvaćeno je 7455 korisnika (učenici, studenti, knjižničari i šira javnost). Ostvarene su brojne suradnje sa školama, sveučilištima, institutima, otvorenim učilištima, kinima, udrugama i građanskim inicijativama.

Dio predavanja organiziranih u sklopu projekta „Zelena knjižnica“ uključen je u čak pet kolegija na Fakultetu za ekonomiju i turizam "Dr. Mijo Mirković” u Puli.

Logotip projekta nastao je u suradnji sa zagrebačkom akademskom slikaricom Teom Hatadi. Budući da je projekt započeo 2011. godine, koja je bila Međunarodna godina šuma, stablo se na logotipu nametnulo kao logičan izbor (slika 1). Otvorena knjiga koja se stapa s krošnjom stabla simbolizira knjižnice, a žuta i plava boja predstavljaju sunce i vodu. Sunce, voda i stablo predstavljaju život, a knjiga predstavlja učenje i spoznaju održivog sustava koji ne ugrožava život na planetu. Istarski model zelene knjižnice potaknuo je širenje „zelenih“ programa na nacionalnoj razini u svim vrstama knjižnica i jedan je od glavnih razloga osnivanja Radne grupe za zelene knjižnice pri Hrvatskom knjižničarskom društvu.

Projekt su od 2012. godine financijski podržavali: Ministarstvo kulture Republike Hrvatske, Grad Pula i jedno vrijeme Grad Rovinj.

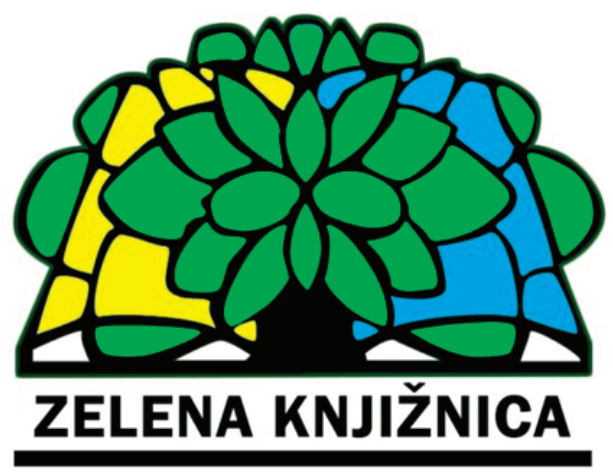

Slika 1. Logotip projekta „Zelena knjižnica“

13 Usp. Kraljević, I. Zelena knjižnica: Projekt Društva bibliotekara Istre. // Vjesnik bibliotekara Hrvatske. 56, 3(2013), 199-204. 
Aktivnosti koje se provode u sklopu projekta Zelena knjižnica uključuju: projekcije dokumentarnih filmova, stručna predavanja, tribine i predstavljanje knjiga ekološke tematike.

Projekt je započeo s aktivnostima 2011. godine, kada Društvo bibliotekara Istre još nije imalo financijska sredstva za pokrivanje troškova, pa je izbor aktivnosti ovisio o predavačima koji su bili voljni doći i održati predavanje o vlastitom trošku ili ponekad o trošku udruge ili ustanove koja je bila suorganizator.

U 2011. godini je unatoč nedostatku financija održana 21 aktivnost u sklopu projekta „Zelena knjižnica“ u Istarskoj županiji. Od samog početka projekta postoji Facebook stranica ${ }^{14}$ na kojoj su dostupne fotografije gotovo svih provedenih aktivnosti s pripadajućim opisima. Isto tako, dostupna je i službena mrežna stranica projekta ${ }^{15}$ Bitno je napomenuti da je, osim navedenih aktivnosti, "Zelena knjižnica" u 2011. godini povezala neke aktiviste iz Društva bibliotekara Istre, Tranzicijska Pule, Gradske radionice, Istarskog eko proizvoda i Zaklade za poticanje partnerstva i razvoja civilnog društva, koji su počeli zajednički djelovati pod nazivom „Inicijativa Pula u tranziciji“. Članovi su se jedno vrijeme okupljali u prostorima Gradske radionice ili u Sveučilišnoj knjižnici u Puli s idejom vodiljom: „Budemo li čekali državu, možda bude prekasno. Budemo li djelovali sami, možda bude premalo. Budemo li djelovali zajedno, možda bude dovoljno i na vrijeme."

Iako se radilo o neformalnoj inicijativi, imali su čak i svoj logo (slika 2). Inicijativa je djelovala do pojave Grupe solidarne razmjene (GSR) u Puli, kada se većina članova inicijative uključila u rad GSR-a.

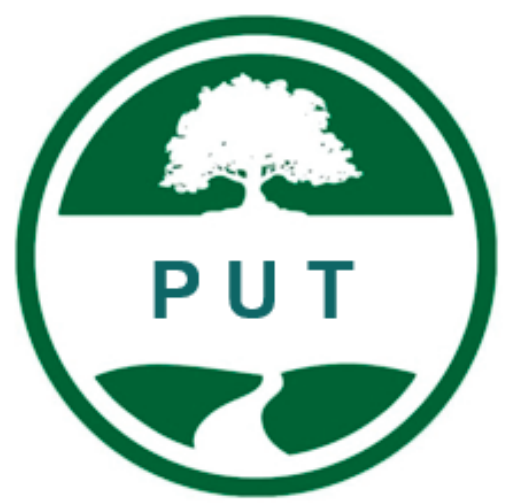

Slika 2. Logo Inicijative Pula u tranziciji

14 Usp. Zelena knjižnica: Projekt. Facebook. // Društvo bibliotekara Istre, 2011. [citirano: 202101-07]. Dostupno na: https://www.facebook.com/zelenaknjiznica.

15 Usp. Zelena knjižnica: Projekt. // Društvo bibliotekara Istre, 2011. [citirano: 2021-01-07]. Dostupno na: http://zk.dbi.hr. 


\section{Doprinos projekta "Zelena knjižnica" ekološkoj osviještenosti i ekološkoj pismenosti studenata}

Sudjelovanje Fakulteta Ekonomije i turizma „Dr. Mijo Mirković“ Pula (FET) u projektu „Zelena knjižnica“ proizlazi iz jasnog opredjeljenja Fakulteta ka implementaciji koncepcije održivih sveučilišta. Održiva su sveučilišta institucije visokog obrazovanja koje promiču održivost u svim aspektima poslovanja, pridonoseći izgradnji odgovornog i konkurentnog gospodarstva, uključivog društva i očuvanju okoliša. Smatra se da institucije visokog obrazovanja imaju osobito važnu ulogu u procesu stvaranja i prijenosa znanja u promicanju održiva razvoja i društveno odgovornog poslovanja. Na sveučilištima se obrazuju i usavršavaju sadašnji i budući stručnjaci i znanstvenici, donositelji strateških odluka s potencijalom preusmjeravanja društva ka održivijim i odgovornijim obrascima življenja i upravljanja resursima. Studenti će nakon završenog studija, kao akademski građani, stečenim znanjem i vještinama, na svojim radnim mjestima i u privatnom životu, značajno utjecati i na kretanje i razvoj društva, gospodarstva i okoliša. Sveučilišta imaju vrlo veliku odgovornost u podizanju osviještenosti i pružanju znanja za izgradnju održivije sadašnjosti i budućnosti ne samo studenata već i dionika u široj zajednici: poslodavaca, udruga, tijela javne vlasti kao i opće javnosti. Uloga sveučilišta očituje se ne samo u obrazovanju „o“ održivom razvoju, već i „,Za“, tj. „kroz“ navedenu koncepciju. Kod obrazovanja o održivom razvoju, primarna uloga sveučilišta jest $u$ transferu znanja i rezultata znanstvenih istraživanja na studente. Kroz nastavni proces sveučilišta imaju priliku i odgovornost obrazovati buduće nositelje promjena i donositelje strateških odluka. Preduvjet navedenog jest obrazovanje i samih nastavnika o načinima konkretne implementacije navedenih koncepcija u nastavnu djelatnost. Pri tome je, u uvjetima stalnih, teško predvidivih i brzih promjena, osobito važno da obrazovanje bude interdisciplinarno i, nerijetko, multidisciplinarno. Kod obrazovanja za održivi razvoj sveučilišta bi trebala aktivnije pristupiti jednoj od svojih misija, a to je djelovanje i partnerstvo sa zajednicom. Aktivnosti djelovanja u zajednici usmjerene su ka unaprjeđenju kvalitete života $u$ zajednici i obrazovanju društveno odgovornih, osviještenih i aktivnih građana. ${ }^{16}$

FET svojim znanstveno-nastavnim i znanstvenoistraživačkim aktivnostima, kao i djelovanjem u lokalnoj i široj društvenoj zajednici, nastoji promicati ekološku svijest i društveno odgovorno poslovanje. U viziji FET-a stoji da je „FET društveno odgovoran centar izvrsnosti u visokom obrazovanju i znanosti te središte poticanja inovativnosti i poduzetničke kulture." FET je svojom misijom prepoznao sljedeće: „Pružanje usluga kvalitetnog visokog obrazovanja u polju ekonomije, unaprjeđenje znanja te doprinos održivom razvoju gospodarstva i bla-

16 Afrić Rakitovac, K. Održiva sveučilišta: Promicatelji društveno odgovornog poslovanja. // 9. konferencija o DOP-u: Zbornik radova. / urednica M. Matešić. Zagreb: Hrvatski poslovni savjet za održivi razvoj, 2017. Str. 20. [citirano: 2020-06-15]. Dostupno na:

https://hrpsor.hr/wp-content/uploads/2020/02/9_Zbornik_web_optim_pdf_3.pdf. 
gostanju zajednice.“17 Stoga sudjelovanje FET-a u projektu „Zelena knjižnica“ pridonosi realizaciji postavljene vizije i misije.

Suradnja Društva bibliotekara Istre i Fakulteta ekonomije i turizma „Dr. Mijo Mirković“" na projektu „Zelena knjižnica“ započela je prvom aktivnošću, tj. projekcijom filma „Dom“ (Home) te se nastavlja do danas. U aktivnostima koje su se odvijale u sklopu „Zelene knjižnice“ korisnici su bili studenti preddiplomskog studija 3. godine (1050 studenata tijekom deset godina) tijekom nastave na kolegijima „Gospodarstvo Hrvatske“ i „Menadžment održiva razvoja“ te studenti diplomskog studija (590 studenata tijekom deset godina) tijekom nastave na kolegijima „Društveno odgovorno poslovanje“, „Održivi turizam“ te „Društvene inovacije i poduzetništvo“.

Prema spomenutim dimenzijama ekološke svijesti, prema Cifriću, može se pretpostaviti da je sudjelovanje studenata u raznolikim aktivnostima projekta ,Zelena knjižnica“ (predavanja, okrugli stolovi, tribine, projekcije filmova, prezentacije vizualnih rješenja, degustacije) pridonijelo njihovoj ekološkoj osviještenosti, znanju o okolišu, stvaranju emocija te spremnosti na zaštitu prirode. Brojni seminarski, završni, diplomski i magistarski radovi pisani su o temama koje su promicane projektom „Zelena knjižnica“.

Prema Turković, „vizualni znanstvenici upućuju na vrijednost vizualnog znanja koje kao svijest o prisutnosti u okolišu može pridonijeti ekološkom ponašanju. “18 Može se pretpostaviti da su projekcije brojnih dokumentarnih filmova tijekom realizacije projekta pridonijele vizualizaciji ekoloških problema, što se smatra značajnim preduvjetom ekološke osviještenosti i ekološke pismenosti.

Svjesni da izravan utjecaj projekata „Zelene knjižnice“ nije moguće precizno utvrditi, smatramo da je upravo raznolikost predstavljenih tema iz različitih područja (biotehnologija, ekologija, ekonomija, energetika, medicina, obrazovanje, prehrana, tehnologija, aktivizam u lokalnoj zajednici i dr.) mogla pridonijeti rutiniziranom svakodnevnom ponašanju sudionika kako studenata tako i šire javnosti.

\section{Zaključak}

Ključan izazov s kojim se suočava sadašnja generacija jest (nanovo, o. a.) osvijestiti i razumjeti međuovisnost ljudskog društva i okoliša u različitim dimenzijama čovjekova djelovanja. U radu je naglasak dan na ulogu knjižnica u promicanju ekološke osviještenosti i ekološke pismenosti. Knjižnice mogu imati vrlo značajnu ulogu u stjecanju znanja, vještina i kompetencija nužnih za kritičko promišlja-

17 Fakultet ekonomije i turizma „Dr. Mijo Mirković“. Vizija, misija i ciljevi. [citirano: 2020-0601]. Dostupno na: http://fet.unipu.hr/fet/o_fakultetu/vizija_misija_i_ciljevi.

18 Turković, V. Značajnost vizualizacije ekoloških problema. // Socijalna ekologija 5, 2(1996), str. 243. [citirano: 2020-05-12]. Dostupno na: https://hrcak.srce.hr/141443. 
nje i djelovanje koje će rezultirati gospodarskim napretkom, uključivim društvom i očuvanim okolišem.

Projekt Društva bibliotekara Istre „Zelena knjižnica“ prvi je, najaktivniji i najdugovječniji projekt u Hrvatskoj koji promiče teme okolišne problematike i održivog društva kroz knjižnice i knjižničarska društva. Od samog početka 2011. godine kada je pokrenut pa do kraja 2019. godine održano je $168^{19}$ javnih aktivnosti na kojima je sudjelovalo 7675 korisnika. Od početka projekta postoji mrežna stranica i službena Facebook stranica projekta na kojima se mogu pratiti najave, ali i vidjeti protekle aktivnosti. S ciljem stalne edukacije šire javnosti pokrenut je i YouTube kanal ${ }^{20}$ na kojemu se mogu vidjeti i čuti neka predavanja koja su bila organizirana tijekom proteklih devet godina. Projekt je inspirirao druge knjižnice i društva te nadahnuo i pokretanje Radne grupe za zelene knjižnice pri Hrvatskom knjižničarskom društvu koja je organizirala Zeleni festival, ${ }^{21} 1$. međunarodnu konferenciju za zelene knjižnice ${ }^{22}$ te kontinuirano svake godine organizira zajedničku akciju „Pokrenimo zelene knjižnice“ i „OdrŽive tribine Let’s Go Green!“.

\section{LITERATURA}

Afrić Rakitovac, K. Održiva sveučilišta: Promicatelji društveno odgovornog poslovanja. // 9. konferencija o DOP-u: Zbornik radova. / urednica M. Matešić. Zagreb: Hrvatski poslovni savjet za održivi razvoj, 2017. Str. 17-29. [citirano: 2020-06-15]. Dostupno na: https://www.hrpsor.hr/wp-content/uploads/2020/02/9_Zbornik_web_ optim_pdf_3.pdf.

Cifrić, I. Ekološka pismenost između kulturne tradicije i ekološke svakodnevnice. // Socijalna ekologija 5, 3 (1996), 403-421.

19 U radu se navode samo aktivnosti koje su bile javnog karaktera, dok se u izvještajima bilježe i aktivnosti kao što su sastanci i putovanja u svrhu istraživanja, dogovaranja i organizacije pojedinih aktivnosti, izrada i dizajn mrežnih stranica i propagandnih materijala i slično pa je gledajući izvještaje, broj aktivnosti veći od navedenih u ovom radu. Isto je tako broj korisnika koji se navodi u izvještajima neznatno veći nego što je navedeno u ovom radu jer su se neke aktivnosti Radne grupe za zelene knjižnice odvijale u sinergiji s projektom „Zelene knjižnice“, a iste nisu prikazane u ovom radu putem broja zastupljenih korisnika.

20 Usp. DBIstre. YouTube. [citirano: 2021-01-07]. Dostupno na: https://www.youtube.com/ user/DBIstre/videos.

${ }_{21}$ Zeleni festival: (O)krenimo na zeleno. // Nacionalna i sveučilišna knjižnica, 2017. [citirano: 2021-01-07]. Dostupno na: http://www.nsk.hr/zeleni-festival-okrenimo-na-zeleno.

22 Međunarodna konferencija o zelenim knjižnicama „Let’s Go Green!“”. // Nacionalna i sveučilišna knjižnica, 2018. [citirano: 2021-01-07]. Dostupno na: http://www.nsk.hr/u-organizaciji-nacionalne-i-sveucilisne-knjiznice-u-zagrebu-odrzana-1-medunarodna-konferencija-o-zelenim-knjiznicama-lets-go-green. 
Cifrić, I. Ekološka edukacija: Utjecaj na oblikovanje novog identiteta? // Filozofska istraživanja 25, 2(2005), 527-544.

Coffey, C.; P. Espinoza Revollo; R. Harvey; M. Lawson; A. Parvez Butt; K. Piaget; D. Sarosi i suradnici. Time to care: Unpaid and underpaid care work and the global inequality crisis. Oxford: Oxfam International, 2020. [citirano: 2020-06-10]. Dostupno na:

http://oxfamilibrary.openrepository.com/bitstream/handle/10546/620928/bp-timeto-care-inequality-200120-en.pdf.

DBIstre. YouTube. [citirano: 2021-01-07]. Dostupno na: http://www.youtube.com/ user/DBIstre/videos.

Disinger, J.F.; C.E. Roth. Environmental literacy. // ERIC Clearinghouse for Science, Mathematics, and Environmental Education, Columbus Ohio, 1992. [citirano: 2020-06-10]. Dostupno na: http://files.eric.ed.gov/fulltext/ED351201.pdf.

„Dom“ Yanna Arthusa-Bertranda na Sveučilištu Jurja Dobrile u Puli. // Sveučilište Jurja Dobrile u Puli. [citirano: 2020-05-12]. Dostupno na: http://e-nastava.unipu.hr/index.php?id=77\&L=1\%25\%2527\&tx_ttnews\%5Btt news $\% 5 \mathrm{D}=8286 \& \mathrm{cHash}=\mathrm{b} 9 \mathrm{efd} 16 \mathrm{a} 2446 \mathrm{e} 4 \mathrm{dd} 445875 \mathrm{a} 29 \mathrm{bc684b} 1$.

Dragaš, B. Zelene knjižnice za zelenu pismenost: Hrvatsko iskustvo. // Vjesnik bibliotekara Hrvatske 60, 4(2017), 221-241.

Fakultet ekonomije i turizma „Dr. Mijo Mirković“. Vizija, misija i ciljevi. [citirano: 2020-05-12]. http://fet.unipu.hr/fet/o_fakultetu/vizija_misija_i_ciljevi.

IFLA (2016): Pristup i mogućnost svima: Kako knjižnice doprinose ostvarivanju Agende Ujedinjenih naroda za održiv razvoj 2030. [citirano: 2020-09-01]. Dostupno na: www.hrdrustvo.hr.

IFLA. Upute: Knjižnice, razvoj i UN-ova AGENDA 2030, kolovoz 2017. Revidirano izd. // Vjesnik bibliotekara Hrvatske 61, 2(2018), 519-543.

Kraljević, I. Djelovanje Radne grupe za zelene knjižnice 2014.-2018. // Vjesnik bibliotekara. 62, 1(2019), 327-340.

Kraljević, I. Zelena knjižnica: Projekt Društva bibliotekara Istre. // Vjesnik bibliotekara Hrvatske. 56, 3(2013), 199-204.

Library Map of the World. [citirano: 2020-06-12]. Dostupno na: https://librarymap. ifla.org.

Međunarodna konferencija o zelenim knjižnicama „Let’s Go Green!“. // Nacionalna i sveučilišna knjižnica, 2018. [citirano: 2021-01-07]. Dostupno na: http://www.nsk. hr/u-organizaciji-nacionalne-i-sveucilisne-knjiznice-u-zagrebu-odrzana-1-medunarodna-konferencija-o-zelenim-knjiznicama-lets-go-green.

Šimleša, D. Ekološki otisak: Kako je razvoj zgazio održivost. Zagreb: Tim Press; Institut društvenih znanosti Ivo Pilar, 2010. 
Turković, V. Značajnost vizualizacije ekoloških problema. // Socijalna ekologija 5, 2(1996), 243-254.

World Wide Fund. Living planet report 2020: Bending the curve of biodiversity loss. [citirano: 2020-07-10]. Dostupno na: https://f.hubspotusercontent20.net/hubfs/4783129/LPR/PDFs/ENGLISH-FULL. pdf.

Zelena knjižnica: Projekt. // Društvo bibliotekara Istre, 2011. [citirano: 2021-01-07]. Dostupno na: http://zk.dbi.hr.

Zelena knjižnica: projekt. Facebook. // Društvo bibliotekara Istre, 2011. [citirano: 202101-07]. Dostupno na: https://www.facebook.com/zelenaknjiznica.

Zeleni festival: (O)krenimo na zeleno. // Nacionalna i sveučilišna knjižnica, 2017. [citirano: 2021-01-07]. Dostupno na: http://www.nsk.hr/zeleni-festival-okrenimo-na-zeleno.

\section{Arhivsko gradivo - arhiva Društva bibliotekara Istre}

Zelena knjižnica: projekt Društva bibliotekara Istre. Izvješće za 2011. godinu. Pula, 2012.

Zelena knjižnica: projekt Društva bibliotekara Istre. Izvješće za 2012. godinu. Pula, 2013.

Zelena knjižnica: projekt Društva bibliotekara Istre. Izvješće za 2013. godinu. Pula, 2014.

Zelena knjižnica: projekt Društva bibliotekara Istre. Izvješće za 2014. godinu. Pula, 2015.

Zelena knjižnica: projekt Društva bibliotekara Istre. Izvješće za 2015. godinu. Pula, 2016.

Zelena knjižnica: projekt Društva bibliotekara Istre. Izvješće za 2016. godinu. Pula, 2017.

Zelena knjižnica: projekt Društva bibliotekara Istre. Izvješće za 2017. godinu. Pula, 2018.

Zelena knjižnica: projekt Društva bibliotekara Istre. Izvješće za 2018. godinu. Pula, 2019.

Zelena knjižnica: projekt Društva bibliotekara Istre. Izvješće za 2019. godinu. Pula, 2020. 


\section{PRILOZI: \\ AKTIVNOSTI PROVEDENE \\ OD 2011. DO KRAJA 2019. GODINE ${ }^{23}$}

\section{Prilog 1: Predavanja}

\begin{tabular}{|c|c|c|c|c|c|}
\hline & Predavač & Naslov predavanja & Mjesto održavanja & Datum & $\begin{array}{c}\text { Broj ko- } \\
\text { risnika }\end{array}$ \\
\hline 1. & $\begin{array}{l}\text { Dražen Šim- } \\
\text { leša }\end{array}$ & $\begin{array}{l}\text { Predstavljanje knjige } \\
\text { Ekološki otisak: Kako } \\
\text { je razvoj zgazio održi- } \\
\text { vost }^{24}\end{array}$ & $\begin{array}{l}\text { Odjel za ekonomiju } \\
\text { i turizam „Dr. Mijo } \\
\text { Mirković u Puli““/ } \\
\text { Gradska knjižnica } \\
\text { Umag / Gradska } \\
\text { knjižnica Pazin }\end{array}$ & $\begin{array}{l}\text { 13. trav- } \\
\text { nja / } 12 . \\
\text { svibnja, } \\
\text { 2011./ } 25 . \\
\text { svibnja }\end{array}$ & 150 \\
\hline 2. & $\begin{array}{l}\text { Kristina } \\
\text { Afrić Raki- } \\
\text { tovac i Irena } \\
\text { Vukmanov } \\
\text { Šimokov } \\
\end{array}$ & $\begin{array}{l}\text { Fair Trade: sustav } \\
\text { pravedne trgovine }\end{array}$ & $\begin{array}{l}\text { Sveučilišna knjižnica } \\
\text { u Puli }\end{array}$ & $\begin{array}{l}26.5 . \\
2011 .\end{array}$ & 20 \\
\hline 3. & Vjeran Piršić & $\begin{array}{l}\text { Sukob neoliberalne } \\
\text { paradigme i koncepta } \\
\text { održivog razvoja - } \\
\text { trajni generator deva- } \\
\text { stacije Hrvatske }\end{array}$ & $\begin{array}{l}\text { Odjel za ekonomiju } \\
\text { i turizam „Dr. Mijo } \\
\text { Mirković u Puli““ }\end{array}$ & 7. 6. 2011. & 50 \\
\hline 4. & Zoran Skala & $\begin{array}{l}\text { Kako se lokalno nositi } \\
\text { s krizom? }\end{array}$ & $\begin{array}{l}\text { Odjel za ekonomiju } \\
\text { i turizam „Dr. Mijo } \\
\text { Mirković u Puli““ }\end{array}$ & 7. 6. 2011. & 50 \\
\hline 5. & Valter Buršić & $\begin{array}{l}\text { Šuma i biološka raz- } \\
\text { nolikost }\end{array}$ & $\begin{array}{l}\text { Sveučilišna knjižnica } \\
\text { u Puli }\end{array}$ & $\begin{array}{l}27.9 . \\
2011 .\end{array}$ & 50 \\
\hline 6. & Emir Komić & $\begin{array}{l}\text { Zdravo, besplatno i } \\
\text { nužno: preživjeti u } \\
\text { šumi }\end{array}$ & $\begin{array}{l}\text { Sveučilišna knjižnica } \\
\text { u Puli }\end{array}$ & $\begin{array}{l}\text { 4. } 10 . \\
2011 .\end{array}$ & 60 \\
\hline 7. & $\begin{array}{l}\text { Mladen } \\
\text { Domazet }\end{array}$ & Klima 2047. godine ${ }^{25}$ & $\begin{array}{l}\text { Odjel za ekonomiju } \\
\text { i turizam „Dr. Mijo } \\
\text { Mirković u Puli“‘ }\end{array}$ & $\begin{array}{l}10.11 . \\
2011 .\end{array}$ & 80 \\
\hline
\end{tabular}

23 Prilozi 1, 2 i 3 nastali su uvidom u godišnja izvješća projekta „Zelena knjižnica“ Društva bibliotekara Istre od 2011. do 2019. godine.

24 Knjigu je izdao Institut društvenih znanosti Ivo Pilar 2010. godine.

25 Zanimljivo je napomenuti da $u$ tom trenutku pitanje klimatskih promjena još nije bilo ni blizu političkog i medijskog fokusa kao što to počinje biti od 2018. godine do sada. 


\begin{tabular}{|c|c|c|c|c|c|}
\hline & Predavač & Naslov predavanja & Mjesto održavanja & Datum & $\begin{array}{l}\text { Broj ko- } \\
\text { risnika }\end{array}$ \\
\hline 8. & Zoran Skala & $\begin{array}{l}\text { Predstavljanje hrvat- } \\
\text { skog izdanja priručni- } \\
\text { ka Postkarbonski gra- } \\
\text { dovi Daniela Learcha }\end{array}$ & $\begin{array}{l}\text { Odjel za ekonomiju } \\
\text { i turizam „Dr. Mijo } \\
\text { Mirković u Puli“‘ }\end{array}$ & $\begin{array}{l}17.11 \\
2011 .\end{array}$ & 75 \\
\hline 9. & $\begin{array}{l}\text { Daniel Ba- } \\
\text { laban }\end{array}$ & $\begin{array}{l}\text { O tranzicijskom } \\
\text { pokretu }\end{array}$ & $\begin{array}{l}\text { Sveučilišna knjižnica } \\
\text { u Puli }\end{array}$ & $\begin{array}{l}29.11 . \\
2011 .\end{array}$ & 20 \\
\hline 10. & Vjeran Piršić & EE - otpad & $\begin{array}{l}\text { Sveučilišna knjižni- } \\
\text { ca u Puli i Gradska } \\
\text { knjižnica u Labinu }\end{array}$ & $\begin{array}{l}\text { prosinac, } \\
2011 .\end{array}$ & 25 \\
\hline 11. & $\begin{array}{l}\text { Hrvoje No- } \\
\text { vosel }\end{array}$ & $\begin{array}{l}\text { Biodinamičko gospo- } \\
\text { darenje }\end{array}$ & $\begin{array}{l}\text { Odjel za ekonomiju } \\
\text { i turizam „Dr. Mijo } \\
\text { Mirković u Puli““ }\end{array}$ & $\begin{array}{l}10.1 . \\
2012 .\end{array}$ & 50 \\
\hline 12. & $\begin{array}{l}\text { Ivan Crn- } \\
\text { ković }\end{array}$ & $\begin{array}{l}\text { Velebitsko utočište za } \\
\text { medvjede }^{26}\end{array}$ & $\begin{array}{l}\text { Gradske knjižnice u } \\
\text { Umagu, Pazinu i Puli }\end{array}$ & $\begin{array}{l}\text { veljača i } \\
\text { ožujak, } \\
2012 .\end{array}$ & 181 \\
\hline 13. & $\begin{array}{l}\text { Nenad } \\
\text { Kuftić }\end{array}$ & $\begin{array}{l}\text { Zeleno poduzetništvo } \\
\text { i grupe solidarne raz- } \\
\text { mjene }^{27}\end{array}$ & $\begin{array}{l}\text { Sveučilišna knjižnica } \\
\text { u Puli }\end{array}$ & $\begin{array}{l}28.2 . \\
2012 .\end{array}$ & 50 \\
\hline 14. & $\begin{array}{l}\text { Ivan Mihovi- } \\
\text { lović }\end{array}$ & Korak do eko markice & $\begin{array}{l}\text { Sveučilišna knjižnica } \\
\text { u Puli }\end{array}$ & $\begin{array}{l}28.2 . \\
2012 .\end{array}$ & 50 \\
\hline 15. & Vjeran Piršić & $\begin{array}{l}\text { Kako osnovati ener- } \\
\text { getsku zadrugu bez } \\
\text { suvišnih zašto? }\end{array}$ & $\begin{array}{l}\text { Odjel za ekonomiju } \\
\text { i turizam „Dr. Mijo } \\
\text { Mirković u Puli““ }\end{array}$ & $\begin{array}{l}27.3 . \\
2012 .\end{array}$ & 75 \\
\hline 16. & $\begin{array}{l}\text { Valerije } \\
\text { Vrček }\end{array}$ & $\begin{array}{l}\text { Druga strana po- } \\
\text { trošačkog raja }\end{array}$ & $\begin{array}{l}\text { Odjel za ekonomiju } \\
\text { i turizam „Dr. Mijo } \\
\text { Mirković u Puli“‘ }\end{array}$ & 3. 4. 2012 . & 40 \\
\hline 17. & Zoran Skala & $\begin{array}{l}\text { Problematika proiz- } \\
\text { vodnje hrane u } 21 \text {. } \\
\text { stoljeću }^{28}\end{array}$ & $\begin{array}{l}\text { Odjel za ekonomiju } \\
\text { i turizam „Dr. Mijo } \\
\text { Mirković u Puli““ }\end{array}$ & $\begin{array}{l}17.4 . \\
2012 .\end{array}$ & 90 \\
\hline 18. & $\begin{array}{l}\text { Ivan Kralje- } \\
\text { vić }\end{array}$ & Zelena knjižnica & $\begin{array}{l}\text { Sveučilišna knjižnica } \\
\text { u Puli }\end{array}$ & $\begin{array}{l}23.4 . \\
2012 .\end{array}$ & 30 \\
\hline
\end{tabular}

26 Na obroncima Velebita, u Kuterevu, nalazi se utočište za medvjediće koji su nesretnim slučajem ili uslijed krivolova odvojeni od majke u dobi kad su premaleni za samostalan život. Takvi mladunci, othranjeni uz pomoć i skrb ljudi, ne uspijevaju razviti znanja i vještine potrebne za samostalan život. Stoga nikad ne odlaze u svoja prirodna staništa nego ostaju u utočištu koje je zasad jedinstven takav projekt u svijetu.

27 Grupe solidarne razmjene (GSR) dugo su djelovale u Puli te se proširile na još neke gradove u Istarskoj županiji. Nakon nekog vremena promijenile su naziv u Solidarne eko grupe (SEG).

28 Predavanjem se obilježio Svjetski dan borbe seljaka za zemlju u sklopu svjetske akcije La Via Campesina. 


\begin{tabular}{|c|c|c|c|c|c|}
\hline & Predavač & Naslov predavanja & Mjesto održavanja & Datum & $\begin{array}{l}\text { Broj ko- } \\
\text { risnika }\end{array}$ \\
\hline 19. & Bruno Motik & Što je permakultura? & $\begin{array}{l}\text { Sveučilišna knjižnica } \\
\text { u Puli }\end{array}$ & $\begin{array}{l}14.5 . \\
2012 .\end{array}$ & 40 \\
\hline 20. & $\begin{array}{l}\text { Vladimir } \\
\text { Lay }\end{array}$ & $\begin{array}{l}\text { Nacionalni interesi } \\
\text { razvoja Hrvatske } \\
\text { kroz prizmu koncepta } \\
\text { održivog razvoja }\end{array}$ & $\begin{array}{l}\text { Sveučilišna knjižnica } \\
\text { u Puli }\end{array}$ & $\begin{array}{l}29.5 . \\
2012 .\end{array}$ & 15 \\
\hline 21. & $\begin{array}{l}\text { Sunčana } \\
\text { Pešak }\end{array}$ & Permakultura i hrana & $\begin{array}{l}\text { Sveučilišna knjižnica } \\
\text { u Puli }\end{array}$ & $\begin{array}{l}20.9 . \\
2012 .\end{array}$ & 40 \\
\hline 22. & $\begin{array}{l}\text { Dražen Šim- } \\
\text { leša }\end{array}$ & Kako nahraniti svijet? & $\begin{array}{l}\text { Sveučilišna knjižnica } \\
\text { u Puli }\end{array}$ & $\begin{array}{l}1.10 . \\
2012 .\end{array}$ & 120 \\
\hline 23. & Mirela Holy & $\begin{array}{l}\text { Održivi razvoj u Hr- } \\
\text { vatskoj s naglaskom } \\
\text { na Istru }\end{array}$ & $\begin{array}{l}\text { Odjel za ekonomiju } \\
\text { i turizam „Dr. Mijo } \\
\text { Mirković u Puli““ }\end{array}$ & $\begin{array}{l}23.10 . \\
2012 .\end{array}$ & 150 \\
\hline 24. & Mladen Šolić & $\begin{array}{l}\text { Umijeće življenja: Iz } \\
\text { kuta jednog ekologa }\end{array}$ & $\begin{array}{l}\text { Sveučilišna knjižnica } \\
\text { u Puli }\end{array}$ & $\begin{array}{l}16.11 . \\
2012 .\end{array}$ & 8 \\
\hline 25. & $\begin{array}{l}\text { Mladen } \\
\text { Domazet }\end{array}$ & $\begin{array}{l}\text { Održivi razvoj: može } \\
\text { li se obrazovati za } \\
\text { promjenu }\end{array}$ & $\begin{array}{l}\text { Odjel za ekonomiju } \\
\text { i turizam „Dr. Mijo } \\
\text { Mirković u Puli““ } \\
\end{array}$ & $\begin{array}{l}11.12 . \\
2012 .\end{array}$ & 75 \\
\hline 26. & Lidija Gajski & $\begin{array}{l}\text { Sukob javnog i privat- } \\
\text { nog interesa u farmaci- } \\
\text { ji i medicini }\end{array}$ & $\begin{array}{l}\text { Odjel za ekonomiju } \\
\text { i turizam „Dr. Mijo } \\
\text { Mirković u Puli““ }\end{array}$ & $\begin{array}{l}17.1 . \\
2013 .\end{array}$ & 150 \\
\hline 27. & Anita Šupe & Istine i laži o hrani & $\begin{array}{l}\text { Gradska knjižnica } \\
\text { Poreč i Sveučilišna } \\
\text { knjižnica u Puli }\end{array}$ & $\begin{array}{l}\text { veljača, } \\
2013 .\end{array}$ & 155 \\
\hline 28. & Ranko Tadić & $\begin{array}{l}\text { Zdravlje ili otrovi u } \\
\text { vašem tanjuru }- \text { u } \\
\text { čemu je bit ekološke } \\
\text { proizvodnje i potroš- } \\
\text { nje hrane? }\end{array}$ & $\begin{array}{l}\text { Sveučilišna knjižnica } \\
\text { u Puli }\end{array}$ & 7.2.2013. & 60 \\
\hline 29. & $\begin{array}{l}\text { Bernard } \\
\text { Ivčić }\end{array}$ & Uvod u ekoaktivizam & $\begin{array}{l}\text { Sveučilišna knjižnica } \\
\text { u Puli }\end{array}$ & $\begin{array}{l}26.2 . \\
2013 .\end{array}$ & 10 \\
\hline 30. & Zoran Skala & $\begin{array}{l}\text { O krizi i ekonomskom } \\
\text { laboratoriju zajednice }\end{array}$ & $\begin{array}{l}\text { Odjel za ekonomiju } \\
\text { i turizam „Dr. Mijo } \\
\text { Mirković u Puli““ }\end{array}$ & $\begin{array}{l}28.3 . \\
2013 .\end{array}$ & 20 \\
\hline 31. & $\begin{array}{l}\text { Sunčana } \\
\text { Pešak }\end{array}$ & $\begin{array}{l}\text { Grupe solidarne raz- } \\
\text { mjene }\end{array}$ & $\begin{array}{l}\text { Gradska knjižnica u } \\
\text { Poreču }\end{array}$ & 8. 4. 2013. & 25 \\
\hline
\end{tabular}




\begin{tabular}{|c|c|c|c|c|c|}
\hline & Predavač & Naslov predavanja & Mjesto održavanja & Datum & $\begin{array}{l}\text { Broj ko- } \\
\text { risnika }\end{array}$ \\
\hline 32. & $\begin{array}{l}\text { Loris Dile- } \\
\text { na }^{29}\end{array}$ & $\begin{array}{l}\text { O starim biljnim sor- } \\
\text { tama Istre, njihovoj } \\
\text { zaštiti i tradicionalnom } \\
\text { uzgoju }\end{array}$ & $\begin{array}{l}\text { Sveučilišna knjižnica } \\
\text { u Puli }\end{array}$ & $\begin{array}{l}15.5 . \\
2013 .\end{array}$ & 40 \\
\hline 33. & $\begin{array}{l}\text { Jagoda } \mathrm{Mu}- \\
\text { nić }\end{array}$ & O održivim društvima & $\begin{array}{l}\text { Sveučilišna knjižnica } \\
\text { u Puli }\end{array}$ & $\begin{array}{l}29.5 . \\
2013 .\end{array}$ & 8 \\
\hline 34. & $\begin{array}{l}\text { Mate Kapo- } \\
\text { vić }\end{array}$ & $\begin{array}{l}\text { Tko nam je kriv, sami } \\
\text { smo ih izabrali? Iluzija } \\
\text { demokracije }\end{array}$ & $\begin{array}{l}\text { Sveučilišna knjižnica } \\
\text { u Puli }\end{array}$ & $\begin{array}{l}20.9 . \\
2013 .\end{array}$ & 27 \\
\hline 35. & $\begin{array}{l}\text { Miroslav } \\
\text { Ambruš-Kiš }\end{array}$ & $\begin{array}{l}\text { O zajamčenom te- } \\
\text { meljnom osobnom } \\
\text { prihodu }\end{array}$ & $\begin{array}{l}\text { Sveučilišna knjižnica } \\
\text { u Puli }\end{array}$ & $\begin{array}{l}24.9 . \\
2013 .\end{array}$ & 18 \\
\hline 36. & $\begin{array}{l}\text { Dražen Šim- } \\
\text { leša }\end{array}$ & $\begin{array}{l}\text { Održivost: modni } \\
\text { trend ili uvjet za } \\
\text { preživljavanje? }\end{array}$ & $\begin{array}{l}\text { Sveučilišna knjižnica } \\
\text { u Puli }\end{array}$ & $\begin{array}{l}19.10 . \\
2013 .\end{array}$ & 10 \\
\hline 37. & $\begin{array}{l}\text { Tihana Ru- } \\
\text { bić, Cvijeta } \\
\text { Biščević, } \\
\text { Marijana } \\
\text { Cvijetić Pir- } \\
\text { šić i Vjeran } \\
\text { Piršić }\end{array}$ & $\begin{array}{l}\text { Predstavljanje zborni- } \\
\text { ka: } \\
\text { O urbanim vrtovima } \\
\text { Kultiviranje grada } \\
\text { Imperativ autohtone } \\
\text { poljoprivredne proiz- } \\
\text { vodnje kao osnovice i } \\
\text { održivog razvoja i gos- } \\
\text { podarskog oporavka }\end{array}$ & $\begin{array}{l}\text { Dom hrvatskih bra- } \\
\text { nitelja }\end{array}$ & $\begin{array}{l}\text { studeni, } \\
2013 .\end{array}$ & 30 \\
\hline 38. & Bruno Motik & $\begin{array}{l}\text { Permakultura kao } \\
\text { globalna društvena } \\
\text { promjena }\end{array}$ & $\begin{array}{l}\text { Sveučilišna knjižnica } \\
\text { u Puli }\end{array}$ & $\begin{array}{l}24.1 . \\
2014 .\end{array}$ & 65 \\
\hline 39. & $\begin{array}{l}\text { Cvijeta } \\
\text { Biščević }\end{array}$ & $\begin{array}{l}\text { Urbana permakultura: } \\
\text { strategije za preživlja- } \\
\text { vanje grada }\end{array}$ & $\begin{array}{l}\text { Sveučilišna knjižnica } \\
\text { u Puli }\end{array}$ & $\begin{array}{l}17.2 . \\
2014 .\end{array}$ & 18 \\
\hline 40. & $\begin{array}{l}\text { Gordana } \\
\text { Dragičević }\end{array}$ & $\begin{array}{l}\text { Tranzicija u post-fosil- } \\
\text { no društvo: kako prob- } \\
\text { lem postaje rješenje }\end{array}$ & $\begin{array}{l}\text { Sveučilišna knjižnica } \\
\text { u Puli }\end{array}$ & $\begin{array}{l}24.2 . \\
2014 .\end{array}$ & 10 \\
\hline
\end{tabular}

29 Loris Dilena je talijanski fotograf, ornitolog, pisac i jedan od najvećih stručnjaka za stare biljne sorte Istre i otoka Cresa. U 40 godina svoga rada sakupio je podatke i fotografije o približno 140 starih sorti, što je samo manji dio onih koje su nekada postojale na tom području, a većine više nema. Nastojeći spriječiti odumiranje preostalog dijela, aktivnim je radom na svom imanju uspio sačuvati mnoge od njih.

30 Aktivnosti održane u suradnji s manifestacijom „Pazi što jedeš“ (projekt Etnografskog muzeja u Istri i udruge Istarski eko proizvod). 


\begin{tabular}{|c|c|c|c|c|c|}
\hline & Predavač & Naslov predavanja & Mjesto održavanja & Datum & $\begin{array}{l}\text { Broj ko- } \\
\text { risnika }\end{array}$ \\
\hline 41. & $\begin{array}{l}\text { Nevija Lon- } \\
\text { go }\end{array}$ & $\begin{array}{l}\text { Urbani vrt u Pazinu: } \\
\text { povrtnjak i cvjetnjak }\end{array}$ & $\begin{array}{l}\text { Gradska knjižnica } \\
\text { Pazin }\end{array}$ & $\begin{array}{l}18.3 . \\
2014 .\end{array}$ & 30 \\
\hline 42. & $\begin{array}{l}\text { Jagoda } \mathrm{Mu}- \\
\text { nić }\end{array}$ & $\begin{array}{l}\text { Prirodni resursi Hr- } \\
\text { vatske - pilimo li gra- } \\
\text { nu na kojoj sjedimo? }\end{array}$ & $\begin{array}{l}\text { Fakultet za ekonomi- } \\
\text { ju i turizam „Dr. Mijo } \\
\text { Mirkovićc، u Puli }\end{array}$ & $\begin{array}{l}21.3 . \\
2014 .\end{array}$ & 70 \\
\hline 43. & Đuro Capor & Pravo na prostor & $\begin{array}{l}\text { Fakultet za ekonomi- } \\
\text { ju i turizam „Dr. Mijo } \\
\text { Mirkovićc u Puli }\end{array}$ & $\begin{array}{l}23.5 . \\
2014 .\end{array}$ & 20 \\
\hline 44. & $\begin{array}{l}\text { Sven Janovs- } \\
\text { ki }\end{array}$ & $\begin{array}{l}\text { Građanski aktivizam i } \\
\text { pravo na okoliš - bor- } \\
\text { ba za javni prostor }\end{array}$ & $\begin{array}{l}\text { Sveučilišna knjižnica } \\
\text { u Puli }\end{array}$ & $\begin{array}{l}30.5 . \\
2014 .\end{array}$ & 29 \\
\hline 45. & Goran Jeras & Etična banka $^{31}$ & $\begin{array}{l}\text { Fakultet za ekonomi- } \\
\text { ju i turizam „Dr. Mijo } \\
\text { Mirković“ u Puli }\end{array}$ & 3. 6. 2014. & 20 \\
\hline 46. & Jelena Puđak & $\begin{array}{l}\text { Društvo visokih } \\
\text { emisija }\end{array}$ & $\begin{array}{l}\text { Sveučilišna knjižnica } \\
\text { u Puli }\end{array}$ & $\begin{array}{l}26.9 . \\
2014 .\end{array}$ & 9 \\
\hline 47. & Daniel Rodik & $\begin{array}{l}\text { Održivo graditeljstvo } \\
\text { - gradnja baliranom } \\
\text { slamom }\end{array}$ & $\begin{array}{l}\text { Sveučilišna knjižnica } \\
\text { u Puli }\end{array}$ & $\begin{array}{l}31.10 . \\
2014 .\end{array}$ & 30 \\
\hline 48. & $\begin{array}{l}\text { Darja Fišer i } \\
\text { Olga Orlić }\end{array}$ & $\begin{array}{l}\text { Predstavljanje projek- } \\
\text { ta: Zelemenjava } \\
\text { Grupe solidarne } \\
\text { razmjene: uspjesi i } \\
\text { poteškoće prilikom } \\
\text { promjene kupovnih i } \\
\text { prehrambenih navika }{ }^{32}\end{array}$ & $\begin{array}{l}\text { Dom hrvatskih } \\
\text { branitelja u Puli }\end{array}$ & $\begin{array}{l}15.11 . \\
2014 .\end{array}$ & 25 \\
\hline 49. & $\begin{array}{l}\begin{array}{l}\text { Ivan Kralje- } \\
\text { vić }\end{array} \\
\end{array}$ & $\begin{array}{l}\text { Predstavljanje projekta } \\
\text { Zelena knjižnica }\end{array}$ & $\begin{array}{l}\text { Gradska knjižnica } \\
\text { Slavonski Brod }\end{array}$ & $\begin{array}{l}6.11 . \\
2014 .\end{array}$ & 40 \\
\hline 50. & Miroslav Kiš & Permakultura & $\begin{array}{l}\text { Sveučilišna knjižnica } \\
\text { u Puli }\end{array}$ & $\begin{array}{l}30.3 . \\
2015 .\end{array}$ & 16 \\
\hline 51. & Vjeran Piršić & $\begin{array}{l}\text { Zeleno gospodarstvo } \\
\text { kao optimalni pravac } \\
\text { razvoja Hrvatske (s } \\
\text { naglaskom na Istru) } \\
\end{array}$ & $\begin{array}{l}\text { Fakultet za ekonomi- } \\
\text { ju i turizam „Dr. Mijo } \\
\text { Mirković“ u Puli }\end{array}$ & $\begin{array}{l}23.4 . \\
2015 .\end{array}$ & 52 \\
\hline 52. & $\begin{array}{l}\text { Mladen } \\
\text { Domazet }\end{array}$ & $\begin{array}{l}\text { Odrast: svjesna pro- } \\
\text { mjena za održivo i } \\
\text { pravedno društvo }\end{array}$ & $\begin{array}{l}\text { Fakultet za ekonomi- } \\
\text { ju i turizam „Dr. Mijo } \\
\text { Mirković“ u Puli }\end{array}$ & $\begin{array}{l}27.4 . \\
2014 .\end{array}$ & 30 \\
\hline
\end{tabular}

31 Etična banka radi na principima etičnog bankarstva: otvorenost, ekološka i društvena osviještenost, demokratičnost upravljanja, transparentnost te reinvestiranje dobiti natrag u zajednicu.

32 Aktivnosti u sklopu suradnje s manifestacijom „Pazi što jedeš“. 


\begin{tabular}{|c|c|c|c|c|c|}
\hline & Predavač & Naslov predavanja & Mjesto održavanja & Datum & $\begin{array}{l}\text { Broj ko- } \\
\text { risnika }\end{array}$ \\
\hline 53. & $\begin{array}{l}\text { Dražen Šim- } \\
\text { leša }\end{array}$ & Četvrti svjetski rat & $\begin{array}{l}\text { Društveni centar } \\
\text { Rojc u Puli }\end{array}$ & 8. 6. 2015. & 35 \\
\hline 54. & $\begin{array}{l}\text { Korado Kor- } \\
\text { lević }\end{array}$ & $\begin{array}{l}\text { Zvjezdane ili neke } \\
\text { druge staze }\end{array}$ & $\begin{array}{l}\text { Fakultet za ekonomi- } \\
\text { ju i turizam „Dr. Mijo } \\
\text { Mirković“ u Puli }\end{array}$ & $\begin{array}{l}17.9 . \\
2015 .\end{array}$ & 300 \\
\hline 55. & Vjeran Piršić & $\begin{array}{l}\text { Zašto klimatske prom- } \\
\text { jene prijete slomom } \\
\text { gospodarstva (i) u Istri } \\
\text { i kako to spriječiti? }\end{array}$ & $\begin{array}{l}\text { Sveučilišna knjižnica } \\
\text { u Puli }\end{array}$ & $\begin{array}{l}7.10 . \\
2015 .\end{array}$ & 17 \\
\hline 56. & $\begin{array}{l}\text { Dževdet } \\
\text { Hadžiseli- } \\
\text { mović, Ne- } \\
\text { ala Ambrosi } \\
\text { Randić, Li- } \\
\text { vija Knaflič } \\
\text { i Ivan Kra- } \\
\text { ljević }\end{array}$ & $\begin{array}{l}\text { Predstavljanje knjige } \\
\text { Dževdeta Hadžiseli- } \\
\text { movića Klima se mi- } \\
\text { jenja, a mi... }\end{array}$ & $\begin{array}{l}\text { Filozofski fakultet } \\
\text { u Puli }\end{array}$ & $\begin{array}{l}29.10 . \\
2015 .\end{array}$ & 47 \\
\hline 57. & Ida Križaj & Ekološka arhitektura & $\begin{array}{l}\text { Sveučilišna knjižnica } \\
\text { u Puli }\end{array}$ & $\begin{array}{l}20.11 . \\
2015 .\end{array}$ & 25 \\
\hline 58. & $\begin{array}{l}\text { Ivan Kralje- } \\
\text { vić }\end{array}$ & $\begin{array}{l}\text { Predstavljanje projekta } \\
\text { „Zelena knjižnica“ }\end{array}$ & $\begin{array}{l}\text { Gradska knjižni- } \\
\text { ca „Ivan Goran } \\
\text { Kovačićc، }\end{array}$ & $\begin{array}{l}26.11 . \\
2015 .\end{array}$ & 19 \\
\hline 59. & $\begin{array}{l}\text { Ivan Kralje- } \\
\text { vić i Petar } \\
\text { Lukačić }\end{array}$ & $\begin{array}{l}\text { Zelene knjižnice u Hr- } \\
\text { vatskoj - edukacijom } \\
\text { do održivog društva }\end{array}$ & $\begin{array}{l}\text { Nacionalna i } \\
\text { sveučilišna knjižnica } \\
\text { u Zagrebu }\end{array}$ & $\begin{array}{l}5.12 . \\
2015 .\end{array}$ & 50 \\
\hline 60. & Ivana Gotić & $\begin{array}{l}\text { Predstavljanje knjige } \\
\text { Ivane Lovrić Zeleni } \\
\text { alati: Prirodna kozme- } \\
\text { tika iz vlastite kuhinje } \\
\text { i radionica prirodne } \\
\text { kozmetike }\end{array}$ & $\begin{array}{l}\text { Sveučilišna knjižnica } \\
\text { u Puli }\end{array}$ & $\begin{array}{l}11.12 . \\
2015 .\end{array}$ & 22 \\
\hline 61. & Dorian Siljan & $\begin{array}{l}\text { Alternativni načini } \\
\text { distribucije ekoloških } \\
\text { proizvoda }\end{array}$ & $\begin{array}{l}\text { Društveni centar } \\
\text { Rojc u Puli }\end{array}$ & $\begin{array}{l}17.12 . \\
2015 .\end{array}$ & 16 \\
\hline 62. & Bruno Motik & Briga o tlu & $\begin{array}{l}\text { Društveni centar } \\
\text { Rojc u Puli }\end{array}$ & $\begin{array}{l}18.12 . \\
2015 .\end{array}$ & 44 \\
\hline 63. & $\begin{array}{l}\text { Sendy Os- } \\
\text { mičević }\end{array}$ & Kućno kompostiranje & $\begin{array}{l}\text { Sveučilišna knjižnica } \\
\text { u Puli }\end{array}$ & 2.5 .2016 . & 30 \\
\hline 64. & Anton Rudan & Lovac na bilje u Istri & $\begin{array}{l}\text { Sveučilišna knjižnica } \\
\text { u Puli }\end{array}$ & $\begin{array}{l}27.5 . \\
2016 .\end{array}$ & 50 \\
\hline
\end{tabular}




\begin{tabular}{|c|c|c|c|c|c|}
\hline & Predavač & Naslov predavanja & Mjesto održavanja & Datum & $\begin{array}{l}\text { Broj ko- } \\
\text { risnika }\end{array}$ \\
\hline 65. & Ivan Zoković & $\begin{array}{l}\text { Energija iz kućne ra- } \\
\text { dinosti }\end{array}$ & $\begin{array}{l}\text { Sveučilišna knjižnica } \\
\text { u Puli }\end{array}$ & $\begin{array}{l}10.6 . \\
2016 .\end{array}$ & 50 \\
\hline 66. & $\begin{array}{l}\text { Renato } \\
\text { Matić }\end{array}$ & $\begin{array}{l}\text { Društveni uzroci } \\
\text { nasilja nad okolišem i } \\
\text { pretpostavke odgoja za } \\
\text { socijalnu osjetljivost o } \\
\text { okolišu }\end{array}$ & $\begin{array}{l}\text { Sveučilišna knjižnica } \\
\text { u Puli }\end{array}$ & $\begin{array}{l}20.6 . \\
2016 .\end{array}$ & 10 \\
\hline 67. & $\begin{array}{l}\text { Korado Kor- } \\
\text { lević }\end{array}$ & $\begin{array}{l}\text { Posljednje stoljeće } \\
\text { Homo sapiensa }\end{array}$ & $\begin{array}{l}\text { Fakultet za ekonomi- } \\
\text { ju i turizam „Dr. Mijo } \\
\text { Mirković“ u Puli }\end{array}$ & $\begin{array}{l}28.9 . \\
2016 .\end{array}$ & 72 \\
\hline 68. & $\begin{array}{l}\text { Mladen } \\
\text { Domazet }\end{array}$ & $\begin{array}{l}\text { Predstavljanje knjige } \\
\text { Odrast-pojmovnik za } \\
\text { novu eru }\end{array}$ & $\begin{array}{l}\text { Fakultet za ekonomi- } \\
\text { ju i turizam „Dr. Mijo } \\
\text { Mirkovićc u Puli }\end{array}$ & $\begin{array}{l}21.10 . \\
2016 .\end{array}$ & 53 \\
\hline 69. & Iva Ciceran & $\begin{array}{l}\text { Predstavljanje projekta } \\
\text { „Zelena knjižnica“ }\end{array}$ & $\begin{array}{l}\text { Spomen dom u Pa- } \\
\text { zinu }\end{array}$ & $\begin{array}{l}5.11 . \\
2016 .\end{array}$ & 40 \\
\hline 70. & $\begin{array}{l}\text { Ivan Kralje- } \\
\text { vić }\end{array}$ & $\begin{array}{l}\text { Zelene knjižnice u } \\
\text { Hrvatskoj }\end{array}$ & $\begin{array}{l}\text { Nacionalna i } \\
\text { sveučilišna knjižnica } \\
\text { u Zagrebu }\end{array}$ & $\begin{array}{l}8.11 . \\
2016 .\end{array}$ & 30 \\
\hline 71. & $\begin{array}{l}\text { Dražen Šim- } \\
\text { leša }\end{array}$ & Dobra ekonomija & $\begin{array}{l}\text { Fakultet za ekonomi- } \\
\text { ju i turizam „Dr. Mijo } \\
\text { Mirković“، u Puli }\end{array}$ & $\begin{array}{l}24.11 . \\
2016 .\end{array}$ & 178 \\
\hline 72. & $\begin{array}{l}\text { Ozren Kosa- } \\
\text { nović i Zo- } \\
\text { rislav Antun } \\
\text { Petrović }\end{array}$ & $\begin{array}{l}\text { Predstavljanje knjige } \\
\text { Suzbijanje korupcije u } \\
\text { Hrvatskoj u srednjem } \\
\text { vijeku II }\end{array}$ & $\begin{array}{l}\text { Sveučilišna knjižnica } \\
\text { u Puli }\end{array}$ & $\begin{array}{l}30.3 . \\
2017 .\end{array}$ & 13 \\
\hline 73. & Vjeran Piršić & $\begin{array}{l}\text { Nova energetska poli- } \\
\text { tika RH - šansa za raz- } \\
\text { voj lokalne ekonomije }\end{array}$ & $\begin{array}{l}\text { Fakultet za ekonomi- } \\
\text { ju i turizam „Dr. Mijo } \\
\text { Mirkovićc، u Puli }\end{array}$ & 7. 4. 2017. & 33 \\
\hline 74. & Bruno Motik & Biotektura & $\begin{array}{l}\text { Sveučilišna knjižnica } \\
\text { u Puli }\end{array}$ & $\begin{array}{l}19.4 . \\
2017 .\end{array}$ & 40 \\
\hline 75. & $\begin{array}{l}\text { Sendy Os- } \\
\text { mičević }\end{array}$ & Urbana permakultura & $\begin{array}{l}\text { Sveučilišna knjižnica } \\
\text { u Puli }\end{array}$ & 1.6. 2017. & 20 \\
\hline 76. & $\begin{array}{l}\text { Valerije } \\
\text { Vrček }\end{array}$ & $\begin{array}{l}\text { (Prvi) biotehnološki } \\
\text { mit - GMO ili kemija! }\end{array}$ & $\begin{array}{l}\text { Sveučilišna knjižnica } \\
\text { u Puli }\end{array}$ & $\begin{array}{l}5.10 . \\
2017 .\end{array}$ & 15 \\
\hline 77. & $\begin{array}{l}\text { Tomislav } \\
\text { Medak }\end{array}$ & $\begin{array}{l}\text { Ekologija i tehnologi- } \\
\text { ja, spas ili propast }\end{array}$ & $\begin{array}{l}\text { Sveučilišna knjižnica } \\
\text { u Puli }\end{array}$ & $\begin{array}{l}12.10 . \\
2017 .\end{array}$ & 27 \\
\hline
\end{tabular}




\begin{tabular}{|c|c|c|c|c|c|}
\hline & Predavač & Naslov predavanja & Mjesto održavanja & Datum & $\begin{array}{l}\text { Broj ko- } \\
\text { risnika }\end{array}$ \\
\hline 78. & $\begin{array}{l}\text { Miroslav } \\
\text { Ambruš-Kiš }\end{array}$ & $\begin{array}{l}\text { Zeleni pogon za istar- } \\
\text { ski teran na Mjesecu }\end{array}$ & $\begin{array}{l}\text { Fakultet za ekonomi- } \\
\text { ju i turizam „Dr. Mijo } \\
\text { Mirković“ u Puli }\end{array}$ & $\begin{array}{l}26.10 . \\
2017 .\end{array}$ & 17 \\
\hline 79. & $\begin{array}{l}\text { Ivana } \\
\text { Vinković } \\
\text { Vrček }\end{array}$ & $\begin{array}{l}\text { Aditivi u hrani: vodič } \\
\text { kroz E brojeve }\end{array}$ & $\begin{array}{l}\text { Fakultet za ekonomi- } \\
\text { ju i turizam „Dr. Mijo } \\
\text { Mirković“، u Puli }\end{array}$ & $\begin{array}{l}22.11 . \\
2017 .\end{array}$ & 100 \\
\hline 80. & Goran Jeras & Etična banka & $\begin{array}{l}\text { Fakultet za ekonomi- } \\
\text { ju i turizam „Dr. Mijo } \\
\text { Mirković“ u Puli }\end{array}$ & $\begin{array}{l}7.12 . \\
2017 .\end{array}$ & 165 \\
\hline 81. & $\begin{array}{l}\text { Cvijeta } \\
\text { Biščević }\end{array}$ & $\begin{array}{l}\text { Urbana permakultura: } \\
\text { kultiviranje grada }\end{array}$ & $\begin{array}{l}\text { Sveučilišna knjižnica } \\
\text { u Puli }\end{array}$ & $\begin{array}{l}15.3 . \\
2018 .\end{array}$ & 19 \\
\hline 82. & $\begin{array}{l}\text { Desanka } \\
\text { Sarvan }\end{array}$ & $\begin{array}{l}\text { Efekti privatizacije } \\
\text { upravljanja vodnim } \\
\text { uslugama }\end{array}$ & $\begin{array}{l}\text { Fakultet za ekonomi- } \\
\text { ju i turizam „Dr. Mijo } \\
\text { Mirković“ u Puli }\end{array}$ & $\begin{array}{l}21.3 . \\
2018 .\end{array}$ & 80 \\
\hline 83. & $\begin{array}{l}\text { Silvija Ko- } \\
\text { lar-Fodor }\end{array}$ & $\begin{array}{l}\text { Vrtlarenje u skladu s } \\
\text { prirodom }\end{array}$ & $\begin{array}{l}\text { Sveučilišna knjižnica } \\
\text { u Puli }\end{array}$ & 5. 4. 2018 . & 75 \\
\hline 84. & $\begin{array}{l}\text { Nikola } \\
\text { Biliškov }\end{array}$ & $\begin{array}{l}\text { Drugačija energetika } \\
\text { je moguća! }\end{array}$ & $\begin{array}{l}\text { Fakultet za ekonomi- } \\
\text { ju i turizam „Dr. Mijo } \\
\text { Mirković“، u Puli }\end{array}$ & $\begin{array}{l}26.4 . \\
2018 .\end{array}$ & 27 \\
\hline 85. & $\begin{array}{l}\text { Branko } \\
\text { Ančić }\end{array}$ & $\begin{array}{l}\text { Klimatske promjene i } \\
\text { zdravlje }\end{array}$ & $\begin{array}{l}\text { Fakultet za ekonomi- } \\
\text { ju i turizam „Dr. Mijo } \\
\text { Mirković“ u Puli }\end{array}$ & $\begin{array}{l}30.5 . \\
2018 .\end{array}$ & 30 \\
\hline 86. & Boris Pavlin & $\begin{array}{l}\text { Energija u rukama } \\
\text { građana }\end{array}$ & $\begin{array}{l}\text { Sveučilišna knjižnica } \\
\text { u Puli }\end{array}$ & $\begin{array}{l}14.6 . \\
2018 .\end{array}$ & 20 \\
\hline 87. & $\begin{array}{l}\text { Mladen Do- } \\
\text { mazet i Ivan } \\
\text { Kraljević }\end{array}$ & $\begin{array}{l}\text { Predstavljanje knjige } \\
\text { Fosilni kapital An- } \\
\text { dreasa Malma }\end{array}$ & $\begin{array}{l}\text { Sveučilišna knjižnica } \\
\text { u Puli }\end{array}$ & $\begin{array}{l}9.10 . \\
2018 .\end{array}$ & 8 \\
\hline 88. & $\begin{array}{l}\text { Sendy Os- } \\
\text { mičević }\end{array}$ & $\begin{array}{l}\text { Društvena banka } \\
\text { sjemena i razmjena } \\
\text { sjemena }\end{array}$ & $\begin{array}{l}\text { Sveučilišna knjižnica } \\
\text { u Puli }\end{array}$ & $\begin{array}{l}18.10 . \\
2018 .\end{array}$ & 26 \\
\hline 89. & $\begin{array}{l}\text { Marija Braj- } \\
\text { dić Vuković }\end{array}$ & Ekologija i pravda & $\begin{array}{l}\text { Fakultet za ekonomi- } \\
\text { ju i turizam „Dr. Mijo } \\
\text { Mirković“ u Puli }\end{array}$ & $\begin{array}{l}25.10 . \\
2018 .\end{array}$ & 25 \\
\hline 90. & Vjeran Piršić & $\begin{array}{l}\text { Energetska tranzicija } \\
\text { kao generator novih } \\
\text { radnih mjesta }\end{array}$ & $\begin{array}{l}\text { Fakultet za ekonomi- } \\
\text { ju i turizam „Dr. Mijo } \\
\text { Mirković“، u Puli }\end{array}$ & $\begin{array}{l}21.3 . \\
2019 .\end{array}$ & 63 \\
\hline 91. & $\begin{array}{l}\text { Mladen Ilič- } \\
\text { ković }\end{array}$ & $\begin{array}{l}\text { Empatijom do za- } \\
\text { okreta }\end{array}$ & $\begin{array}{l}\text { Fakultet za ekonomi- } \\
\text { ju i turizam "Dr. Mijo } \\
\text { Mirković" u Puli }\end{array}$ & $\begin{array}{l}11.4 . \\
2019 .\end{array}$ & 39 \\
\hline
\end{tabular}




\begin{tabular}{|c|c|c|c|c|c|}
\hline & Predavač & Naslov predavanja & Mjesto održavanja & Datum & $\begin{array}{l}\text { Broj ko- } \\
\text { risnika }\end{array}$ \\
\hline 92. & Zoran Skala & $\begin{array}{l}\text { Globalno zatopljenje i } \\
\text { mentalno ledeno doba }\end{array}$ & $\begin{array}{l}\text { Sveučilišna knjižnica } \\
\text { u Puli }\end{array}$ & 9. 5. 2019. & 18 \\
\hline 93. & Bruno Motik & $\begin{array}{l}\text { Poljoprivreda je } \\
\text { rješenje za sve prob- } \\
\text { leme }\end{array}$ & $\begin{array}{l}\text { Sveučilišna knjižnica } \\
\text { u Puli }\end{array}$ & $\begin{array}{l}14.6 . \\
2019 .\end{array}$ & 20 \\
\hline 94. & Iva Maslovar & $\begin{array}{l}\text { Predstavljanje projekta } \\
\text { otvorenih njiva }\end{array}$ & $\begin{array}{l}\text { Sveučilišna knjižnica } \\
\text { u Puli }\end{array}$ & $\begin{array}{l}14.6 . \\
2019 .\end{array}$ & 20 \\
\hline 95. & $\begin{array}{l}\text { Vedran Hor- } \\
\text { vat }\end{array}$ & $\begin{array}{l}\text { Zelena politika - od } \\
\text { aktivizma do instituci- } \\
\text { ja i nazad }\end{array}$ & $\begin{array}{l}\text { Sveučilišna knjižnica } \\
\text { u Puli }\end{array}$ & $\begin{array}{l}\text { 17. } 10 . \\
2019 .\end{array}$ & 9 \\
\hline 96. & Đani Benčić & $\begin{array}{l}\text { Ekološko maslinarstvo } \\
\text { - izazov za budućnost } \\
\text { Istre i Hrvatske }\end{array}$ & $\begin{array}{l}\text { Sveučilišna knjižnica } \\
\text { u Puli }\end{array}$ & $\begin{array}{l}21.11 . \\
2019 .\end{array}$ & 38 \\
\hline
\end{tabular}

\section{Prilog 2: Filmske projekcije}

\begin{tabular}{|l|l|l|l|c|}
\hline \multicolumn{1}{|c|}{ Projekcija filma } & \multicolumn{1}{c|}{ Mjesto održavanja } & \multicolumn{1}{c|}{ Datum } & $\begin{array}{c}\text { Broj ko- } \\
\text { risnika }\end{array}$ \\
\hline 1. & $\begin{array}{l}\text { Tri projekcije filma Dom } \\
\text { Yanna Arthusa Bertranda }\end{array}$ & Kina Valli, Pula & $\begin{array}{l}4 . \text { i 7. 04. } \\
2011 .\end{array}$ & 500 \\
\hline 2. & $\begin{array}{l}\text { Priča o stvarima } \\
\text { Leonard }\end{array}$ & $\begin{array}{l}\text { Sveučilišna knjižnica u } \\
\text { Puli te gradske knjižnice } \\
\text { u Buzetu, Labinu i Paz- } \\
\text { inu }\end{array}$ & $\begin{array}{l}\text { svibanj, } \\
2011 .\end{array}$ & 200 \\
\hline 3. & Istina o mesu $^{34}$ & $\begin{array}{l}\text { Sveučilišna knjižnica u } \\
\text { Puli }\end{array}$ & 4. 10. 2011. & 60 \\
\hline 4. & $\begin{array}{l}\text { Utranziciji } \\
\text { Emme Goude }\end{array}$ & $\begin{array}{l}\text { Sveučilišna knjižnica u } \\
\text { Puli }\end{array}$ & $\begin{array}{l}29.11 . \\
2011 .\end{array}$ & 20 \\
\hline
\end{tabular}

33 The Story of Stuff, film iz 2007. godine koji govori o našoj opsjednutošću stvarima, odnosno o neodrživom razvoju potrošačkoga društva u kojem živimo.

34 Meat the Truth je nizozemski dokumentarni film iz 2007. godine koji ukazuje na do tada slabo isticanu činjenicu da mesna industrija stvara više emisija stakleničkih plinova nego sav svjetski promet.

35 In Transition 1.0 je američki dokumentarni film iz 2009. godine koji govori o tranzicijskom pokretu. 


\begin{tabular}{|c|c|c|c|c|}
\hline & Projekcija filma & Mjesto održavanja & Datum & $\begin{array}{c}\text { Broj ko- } \\
\text { risnika }\end{array}$ \\
\hline 5. & $\begin{array}{l}\text { Crno } \text { zlato }^{36} \text { redatelja Mar- } \\
\text { ca James Francisa i Nick } \\
\text { Francisa }\end{array}$ & $\begin{array}{l}\text { Sveučilišna knjižnica u } \\
\text { Puli }\end{array}$ & 17. 2. 2012 . & 40 \\
\hline 6. & $\begin{array}{l}\text { Moć zajednice: Kako je } \\
\text { Kuba preživjela naftnu } \\
\text { krizu }\end{array}$ & $\begin{array}{l}\text { Sveučilišna knjižnica u } \\
\text { Puli }\end{array}$ & 13. 3. 2012. & 40 \\
\hline 7. & $\begin{array}{l}\text { Ratnik smeć } a^{38} \text { redatelja } \\
\text { Olivera Hodgea }\end{array}$ & $\begin{array}{l}\text { Sveučilišna knjižnica u } \\
\text { Puli }\end{array}$ & 12. 6. 2012. & 50 \\
\hline 8. & $\begin{array}{l}\text { U Tranziciji } 2.0^{39} \text { redateljice } \\
\text { Emme Goude i rasprava o } \\
\text { tranziciji }\end{array}$ & $\begin{array}{l}\text { Sveučilišna knjižnica u } \\
\text { Puli }\end{array}$ & 21. 3. 2013. & 40 \\
\hline 9. & $\begin{array}{l}\text { Moć zajednice: Kako je } \\
\text { Kuba preživjela naftnu } \\
\text { krizu i izlaganje savjetnika } \\
\text { kubanskog veleposlanika u } \\
\text { Austriji Salvadora Cabeiro } \\
\text { Quintane o iskustvima živo- } \\
\text { ta u Kubi tijekom velike } \\
\text { krize } 90 \text {-ih. }\end{array}$ & $\begin{array}{l}\text { Odjel za ekonomiju i tur- } \\
\text { izam „Dr. Mijo Mirković } \\
\text { u Puli““ }\end{array}$ & 22. 4. 2013. & 70 \\
\hline 10. & $\begin{array}{l}\text { U Tranziciji } 2.0 \text { redateljice } \\
\text { Emme Goude. }\end{array}$ & Gradska knjižnica Labin & 23. 4. 2013. & 40 \\
\hline 11. & $\begin{array}{l}\text { Taste the Waste }{ }^{40} \text { (Okusi } \\
\text { smeće) redatelja Valentin } \\
\text { Thurn }\end{array}$ & $\begin{array}{l}\text { Narodna knjižnici u Bu- } \\
\text { zetu, Sveučilišna knjiž- } \\
\text { nica u Puli i Gradska } \\
\text { knjižnici u Pazinu }\end{array}$ & $\begin{array}{l}\text { svibanj, } \\
2013 .\end{array}$ & 85 \\
\hline
\end{tabular}

36 Black Gold: Wake up and smell the coffee je američki dokumentarni film iz 2006. godine koje obrađuje problematiku pravedne trgovine na primjeru proizvodnje kave.

37 The Power of community: How Cuba survived peak oil, američki dokumentarni film iz 2006. godine koji prikazuje veliku naftnu krizu u Kubi 90-ih godina te snagu zajednica koja se prilagodila novom načinu života.

38 Garbage Warrior, britanski dokumetarni film iz 2008. godine koji donosi epsku priču američkog arhitekta Michaela Reynoldsa o njegovoj borbi za uvođenje radikalno održivog stanovanja.

39 In Transition 2.0, britanski dokumentarni film iz 2012. godine koji obrađuje temu tranzicijskog pokreta.

40 Njemački dokumentarni film iz 2011. godine koji se bavi globalnim problemom bacanja i uništavanja hrane. Valentin Thurn (scenarist i redatelj filma) gostovao je na zagrebačkoj promociji filma koju je u sklopu projekta „Jestivi grad“ organizirao Goethe-Institut Kroatien u veljači 2012. godine. 


\begin{tabular}{|c|c|c|c|c|}
\hline & Projekcija filma & Mjesto održavanja & Datum & $\begin{array}{l}\text { Broj ko- } \\
\text { risnika }\end{array}$ \\
\hline 12. & $\begin{array}{l}\text { Ponosna zelena vatra: bitka } \\
\text { za planet na kojem živimo }{ }^{41}\end{array}$ & Kino Valli & 6.11 .2013$. & 230 \\
\hline 13. & $\begin{array}{l}\text { Sharkwater }{ }^{42} \text { redatelja Rob } \\
\text { Stewarta }\end{array}$ & Kino Valli & 3. 12. 2013 . & 101 \\
\hline 14. & $\begin{array}{l}\text { Nasamareni ste }{ }^{43} \text { redatelja } \\
\text { Anthonya Baxtera }\end{array}$ & Kino Valli & 29. 4. 2014 . & 80 \\
\hline 15. & $\begin{array}{l}\text { Prostorna pravda } 44 \text { redate- } \\
\text { ljica Marte Batinić i Sanje } \\
\text { Kapidžić }\end{array}$ & $\begin{array}{l}\text { Fakultet za ekonomiju } \\
\text { i turizam „Dr. Mijo } \\
\text { Mirković“" u Puli }\end{array}$ & 23. 5. 2014. & 20 \\
\hline 16. & $\begin{array}{l}\text { Predstavljanje i projekcija } \\
\text { filmova iz serijala Obrisi } \\
\text { održive budućnosti }\end{array}$ & $\begin{array}{l}\text { Društveni centar Rojc } \\
\text { u Puli }\end{array}$ & 19. 5. 2015 . & 11 \\
\hline 17. & $\begin{array}{l}\text { Dobar život ("La Buena } \\
\text { Vida”) Jensa Schanzea }\end{array}$ & $\begin{array}{l}\text { Fakultet za ekonomiju } \\
\text { i turizam „Dr. Mijo } \\
\text { Mirković“" u Puli }\end{array}$ & 2. 12. 2015 . & 80 \\
\hline 20. & $\begin{array}{l}\text { Tri projekcije filma Elemen- } \\
\text { tal }^{45} \text { redatelja Gayatri Ro- } \\
\text { shan i Emmanuela Vaughan- } \\
\text { Leea }\end{array}$ & Kino Valli u Puli & 16. 3. 2017. & 600 \\
\hline
\end{tabular}

${ }^{41}$ A Fierce Freen Fire, američki dokumentarni film iz 2012. godine o razvoju pokreta za zaštitu okoliša od 60-ih godina 20. stoljeća pa sve do današnjih dana.

42 Višestruko nagrađivani kanadski dokumentarni film iz 2006. godine koji raskrinkava uvriježene stereotipe i medijsko prikazivanje morskih pasa kao krvožednih čudovišta koja su opasna za čovjeka te otkriva stvarnost tih životinja kao glavnih stupova u evoluciji mora.

43 You've been Trumped, britanski film iz 2011. godine koji problematizira okolišno pitanje izgradnje golf terena. Film je u Puli prikazan na Svjetski dan protiv golfa (World No-Golf Day) u vrijeme kad se pitanje izgradnje golf terena dosta provlačilo po medijima zbog Srđa u Dubrovniku i Muzila u Puli.

44 Kratki dokumentarni film Prostorna pravda (Filmaktiv, 2014.) vodi nas od masovne apartmanizacije vrijednog priobalnog i agrarnog područja projektima izgradnje golf terena u Dubrovniku, Puli i Šibensko-kninskoj županiji, preko privatizacije javnog prostora političkim pogodovanjem i manipulacijom javnim interesom u Zagrebu, do sustavnog isključivanja građana iz procesa odlučivanja.

45 Američki dokumentarni film iz 2013. godine koji putem tri nepovezane priče problematizira globalni problem klimatskih promjena. 


\begin{tabular}{|c|c|c|c|c|}
\hline & Projekcija filma & Mjesto održavanja & Datum & $\begin{array}{l}\text { Broj ko- } \\
\text { risnika }\end{array}$ \\
\hline 21. & $\begin{array}{l}\text { Projekcije filmova: }{ }^{46} \\
\text { Čovjek (Steve Cutts) } \\
\text { Rasti (Micah Levin) } \\
\text { Treće slovo (Grzegorz Jon- } \\
\text { kajtys) } \\
\text { Mni Wiconi: Otpor kod } \\
\text { Standing Rocka (Lucian } \\
\text { Read) } \\
\text { Neposlušnost: Hrabrost } \\
\text { oslobođenja (Kelly Nyks) } \\
\text { Sjeme slobode (Jess Philli- } \\
\text { more) } \\
\text { Američko čudovište Mon- } \\
\text { santo (Abby Martin) } \\
\text { Život jedne plastične vrećice } \\
\text { (Boomerang Bags) } \\
\text { Stavi u vrećicu (Suzan Be- } \\
\text { raza) } \\
\text { Priča o stvarima: Priča o } \\
\text { flaširanoj vodi (Annie Leo- } \\
\text { nard) } \\
\text { Kome treba voda u boci? } \\
\text { (Multimedijalni institut) } \\
\text { Jednostavniji način - kriza } \\
\text { kao prilika (Jordan Osmond) }\end{array}$ & $\begin{array}{l}\text { Društveni centar Rojc } \\
\text { u Puli }\end{array}$ & $\begin{array}{l}9.7 .-12.7 . \\
2017 .\end{array}$ & 47 \\
\hline 22. & $\begin{array}{l}\text { Projekcije filmova Saše } \\
\text { Bešlića: } \\
\text { Utjecaj klimatskih promjena } \\
\text { na obje strane planeta } \\
\text { Penjanje za klimu - Kli- } \\
\text { matske promjene u Eu- } \\
\text { ropskim Alpama } \\
\text { Posljedice na sjevernoj } \\
\text { polutci }\end{array}$ & Kino Valli & 28. 3. 2019. & 450 \\
\hline
\end{tabular}

46 U sklopu 3. nacionalne akcije „Pokrenimo zelene knjižnice“ prikazano je svih 11 filmova s četvrtog E?! - Okolišnog film festivala. 


\section{Prilog 3: Tribine}

\begin{tabular}{|c|c|c|c|c|c|}
\hline & Izlagač & Tribina & $\begin{array}{c}\text { Mjesto } \\
\text { održavanja }\end{array}$ & Datum & $\begin{array}{c}\text { Broj } \\
\text { korisnika }\end{array}$ \\
\hline 1. & $\begin{array}{l}\text { Ljubomir Miščević, } \\
\text { Zoran Skala, Vjeran } \\
\text { Piršić, Ivan Jurković, } \\
\text { Tijana Barbić Domazet, } \\
\text { Josip Zidarić, Ivan } \\
\text { Kraljević, predstavnici } \\
\text { Zelene Istre, predstavnici } \\
\text { Inicijative Pula u tranziciji, } \\
\text { predstavnici Grada Pule }\end{array}$ & $\begin{array}{l}\text { Pula na solarni } \\
\text { pogon }\end{array}$ & $\begin{array}{l}\text { Odjel za } \\
\text { ekonomiju i } \\
\text { turizam „Dr. } \\
\text { Mijo Mirković } \\
\text { u Puli““ }\end{array}$ & $\begin{array}{l}27.1 . \\
2012 .\end{array}$ & 60 \\
\hline 2. & $\begin{array}{l}\text { Sunčana Pešak, Zoran } \\
\text { Skala, Ivan Kraljević }\end{array}$ & $\begin{array}{l}\text { Neodoljivo unosna } \\
\text { glad }^{47}\end{array}$ & $\begin{array}{l}\text { Odjel za } \\
\text { ekonomiju i } \\
\text { turizam „Dr. } \\
\text { Mijo Mirković } \\
\text { u Puli“ }\end{array}$ & $\begin{array}{l}17.4 . \\
2013 .\end{array}$ & 60 \\
\hline 3. & $\begin{array}{l}\text { Jiri Jerabek (Greenpeace), } \\
\text { Dušica Radojčić (Zelena } \\
\text { Istra), Toni Vidan (Zelena } \\
\text { akcija) i Vladimir Jelavić } \\
\text { (EKONERG) }\end{array}$ & $\begin{array}{l}\text { Skriveni troškovi } \\
\text { termoelektrane } \\
\text { Plomin C }\end{array}$ & $\begin{array}{l}\text { Fakultet za } \\
\text { ekonomiju i } \\
\text { turizam „Dr. } \\
\text { Mijo Mirković } \\
\text { u Puli“‘ }\end{array}$ & $\begin{array}{l}17.6 . \\
2013 .\end{array}$ & 35 \\
\hline 4. & $\begin{array}{l}\text { Sunčana Pešak iz Zelene } \\
\text { Mreže Aktivističkih } \\
\text { Grupa, Andrea Vugrinović } \\
\text { - predsjednica Klastera } \\
\text { ekološke poljoprivrede i } \\
\text { Ina Delić - članica Grupe } \\
\text { solidarne razmjene Pula }\end{array}$ & $\begin{array}{l}\text { Utjecaj današnjeg } \\
\text { društva na } \\
\text { zdravlje i okoliš } \\
\text { - uloga ekološke } \\
\text { poljoprivrede }\end{array}$ & $\begin{array}{l}\text { Fakultet za } \\
\text { ekonomiju i } \\
\text { turizam „Dr. } \\
\text { Mijo Mirković } \\
\text { u Puli“ }\end{array}$ & $\begin{array}{l}3.2 . \\
2014 .\end{array}$ & 50 \\
\hline 5. & $\begin{array}{l}\text { (organizirala Udruga } \\
\text { Zelena Istra) }\end{array}$ & $\begin{array}{l}\text { Promjene koje } \\
\text { donosi novi Zakon } \\
\text { o pomorskom } \\
\text { dobru i morskim } \\
\text { lukama: Imaju li } \\
\text { građani pravo na } \\
\text { slobodan pristup } \\
\text { pomorskom dobru? }\end{array}$ & $\begin{array}{l}\text { Društveni } \\
\text { centar Rojc u } \\
\text { Puli }\end{array}$ & $\begin{array}{l}12.9 . \\
2014 .\end{array}$ & 30 \\
\hline 6. & $\begin{array}{l}\text { (organizirala Udruga } \\
\text { Zelena Istra) }\end{array}$ & $\begin{array}{l}\text { Kobni lanac } \\
\text { ugljena }\end{array}$ & $\begin{array}{l}\text { Galerija } \\
\text { Cvajner u Puli }\end{array}$ & $\begin{array}{l}17.2 . \\
2016 .\end{array}$ & 30 \\
\hline
\end{tabular}

47 Ovom se tribinom Društvo bibliotekara Istre već drugu godinu za redom uključilo u globalnu akciju pokreta La Via Campesina. 